


\section{A regular annual sea transport carbon footprint for the islands of Cres and Lošinj}

\section{Ugljikov otisak cjelogodišnjega linijskog pomorskog prometa na otocima Cresu i Lošinju}

The article presents the determination of the local carbon (ecological) footprint of regular annual sea transport for the islands of Cres and Lošinj. In the form of a case study, the article isolates the local environmental load of $\mathrm{CO}_{2}$ emission into the atmosphere as the result of the ferry, and high speed catamaran and ship transport output. Footprints generated by the resident population and tourism's regular sea transport are isolated out as parts of the environmental load. The hypothesis that this article is based upon states that the sea transport's carbon footprint is dominantly under the impact of tourism and shows annual oscillations closely related to the tourism activity on the islands. The article's contribution on the theoretical level is the actualization of isolating partial tourist footprints. On the applicative level, the article's contribution is in the footprint calculations as a basis for the development of the islands and the surrounding areas' sustainable development strategies and plans. The end results of this work are showing that the regular sea transport partial environmental load of $2.3 \%$ of local sea biocapacity can be described as rather small and that tourism's share in this load makes up 36.5\%. The contributions of article results are indicative for the process of revitalization and sustainable development of the islands of Cres and Lošinj as exceptionally preserved and valuable areas.

Key words: carbon footprint, ecological footprint, sea transport, tourism, Island of Cres, Island of Lošinj
U radu se predstavljaju rezultati odredivanja lokalnog ugljikova (ekološkog) otiska cjelogodišnjega linijskog pomorskog prometa na području otoka Cresa i Lošinja. U obliku studije slučaja izdvojeno je lokalno opterećenje okoliša emisijom $\mathrm{CO}_{2}$ u atmosferu kao posljedica cjelogodišnjih trajektnih, brzobrodskih i brodskih linja. U opterećenju okoliša izdvojeni su otisci za potrebe rezidentnog stanovništva i turizmom generirani otisak u linijskome pomorskom prometu. Rad se temelji na hipotezi da je ugljikov otisak pomorskog prometa dominantno pod utjecajem turizma i pokazuje godišnje oscilacije usko vezane uz turističku aktivnost na otocima. Njegov je doprinos na teorijskoj razini aktualizacija izdvajanja parcijalnih turističkih otisaka, a na aplikativnoj razini izračun otisaka kao podloge za razvoj strategija i planova za održivi razvoj otočnih i ostalih prostora. Rezultati rada pokazuju da je parcijalno oterećenje okoliša linijskim pomorskim prometom maleno te iznosi $2,3 \%$ od biokapaciteta lokalnog mora te da turizam u tom opterećenju sudjeluje s 36,5 $\%$. Cilj rada jest doprinos revitalizaciji i održivom razvoju otoka kao prirodno očuvanih i visokovrijednih prostora.

Ključne riječi: ugljikov otisak, ekološki otisak, pomorski promet, turizam, otok Cres, otok Lošinj 
HRVATSKI

GEOGRAFSKI

GLASNIK

77/2, 73-83 (2015.)

\section{Introduction}

Sea transport is a necessary prerequisite for an island's survival. Still, along with positive impacts, this type of transport necessarily has certain environmental impact as well. The research that this article presents tried to encompass that particular impact, and to depict it using the ecological footprint method. The ecological footprint method rates our environmental impact while taking into account the environment's capacity to absorb that impact. In the case of the sea transport, $\mathrm{CO}_{2}$ emissions and the $\mathrm{CO}_{2}$ absorption capacity of Cres and Lošinj's sea were singled out in the form of a case study of the regular annual sea transport environmental impact in the Cres-Lošinj archipelago (Fig. 1).

\section{Uvod}

Odvijanje pomorskog prometa nužna je pretpostavka za život otoka. Ipak, uz pozitivne aspekte taj oblik prometa nužno utječe na okoliš. U istraživanju se pokušalo obuhvatiti taj utjecaj te ga prikazati uz pomoć metode ekološkog otiska, koja stavlja u omjer djelovanje čovjeka na okoliš s obzirom na kapacitet okoliša da to djelovanje prihvati i nosi. U obliku studije slučaja utjecaja na okoliš cjelogodišnjega linijskog pomorskog prometa u cresko-lošinjskom arhipelagu, izdvojene su emisije $\mathrm{CO}_{2} \mathrm{i}$ kapacitet apsorpcije $\mathrm{CO}_{2}$ pripadajućeg mora otoka Cresa i Lošinja (sl. 1).

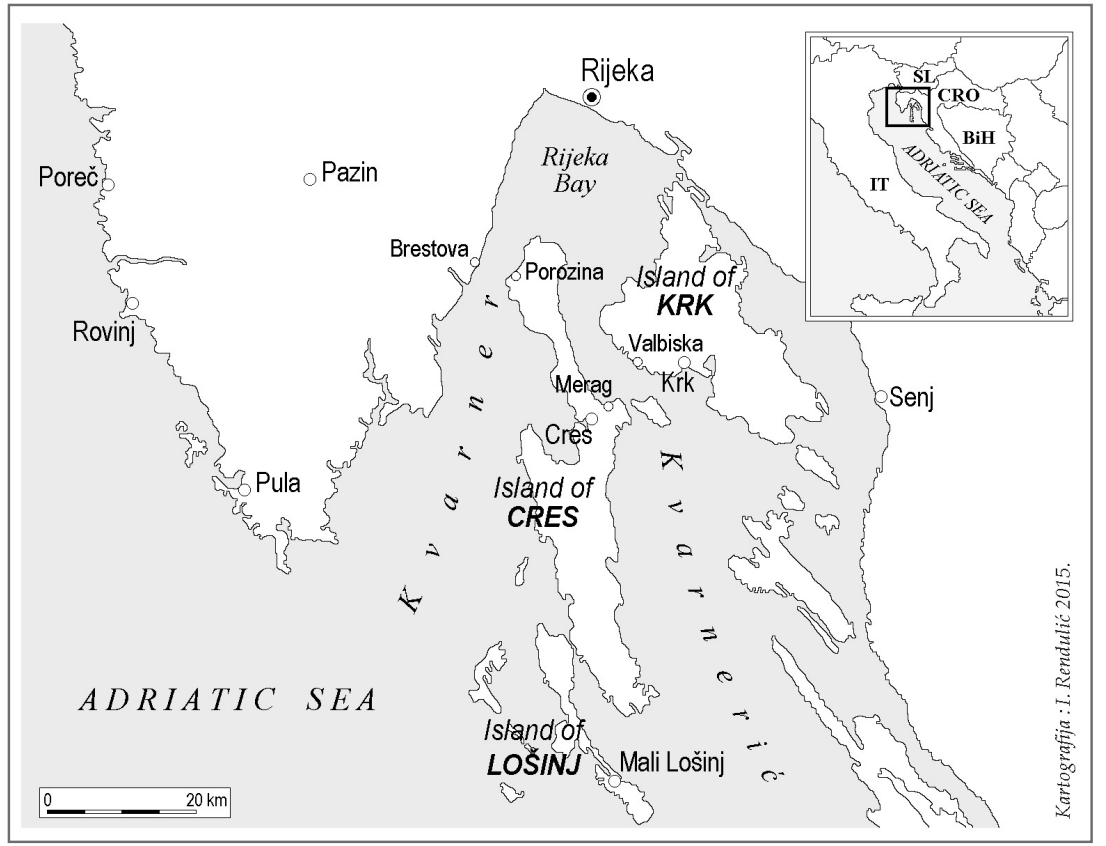

Fig. 1. Position of islands of Cres and Lošini in Northern Adriatic

SI. 1. Smještaj otoka Cresa i Lošinja u Sjevernom Jadranu
The article's aim is to calculate the ecological (carbon) footprint of an annual every day (regular) transport for the islands of Cres and Lošinj, as well as to isolate the tourism-related footprint. The hypothesis on which this work is based says that the sea transport's carbon footprint is dominantly under tourism's influence, showing annual oscillations closely related to the tourism activity on the islands.

The results of this work may be used for development of sustainable strategies and plans of island communities. Assessments of changes on the islands in local rural
Cilj je rada izračun ekološkog (ugljikova) otiska cjelogodišnjega linijskog prometa na otocima Cresu i Lošinju te izdvajanje udjela otiska vezanog uz turizam. Rad se temelji na hipotezi da je ugljikov otisak pomorskog prometa dominantno pod utjecajem turizma i pokazuje godišnje oscilacije usko vezane uz aktivnost turizma na otocima.

Rezultati rada mogu se upotrijebiti za izradu planova i strategija održivog razvoja otočnih zajednica. Prema procjenama, lokalne ruralne strukture, 
structure, and demographic and economic characteristics by 2020 are showing slow movements (Lukić, 2012). The impacts of possible global changes in transport systems on the islands and their transport system are also minor. The global forecast of the modal split of transport till 2020 estimates that the carbon footprint of coastal shipping will not increase significantly (Piecyk and McKinnon, 2010).

This work's contribution on the theoretical level is the actualization of isolation of partial tourism footprints. At the applicative level, its contribution is in the footprints' calculation as the basis for the development of strategies and plans for the sustainable development of islands and other areas. In the end, the overall aim of this work is to contribute to the revitalization and sustainable development of islands as highly valuable areas.

\section{Material and methods}

The research relies on articles that address the tourism impact on the environmental load and deal with calculating the ecological footprint (Hunter, 2002; Hunter and Shaw, 2007), as well as specifically determining the tourism impact on $\mathrm{CO}_{2}$ atmospheric emissions, and assessing tourism's carbon footprint (Grofelnik, 2010; Gössling, 2011; Grofelnik, 2012).

In order to be able to calculate the ecological footprint and sea transport's partial carbon footprint, a contact had been made with the Jadrolinija Company, which is the only carrier for regular sea transport service for the islands of Cres and Lošinj. The carbon footprint was calculated using standard methods (Ewing et al., 2008), along with relevant statistical data. Taking the case study of the annual regular sea transport service carbon footprint as an example, this article presents calculations of the carbon footprint's total environmental impact, with the specifically isolated share of tourism in the footprint.

Considering the medium the sea transport uses, calculated values of $\mathrm{CO}_{2}$ emissions were placed in relation to the local $\mathrm{CO}_{2}$ absorption capacity of the Northern Adriatic Sea, and of the sea area which belongs to the islands of Cres and Lošinj (Laruelle et al., 2010; Turk et al., 2010). In the calculations, the sea area of $3064 \mathrm{~km}^{2}$ that belongs to both of the local territorial units of the Cities of Cres and Mali Lošinj was used. demografska i ekonomska obilježja do 2020. godine na otocima pokazuju blage promjene (Lukić, 2012). Utjecaj mogućih globalnih promjena na prometni sustav na otocima također je zanemariv. Procjene globalnih razvojnih odnosa unutar transportnog sustava na globalnoj razini do 2020. predviđaju da se ugljikov otisak obalnog brodarstva neće značajno povećati (Piecyk i McKinnon, 2010).

Doprinos rada na teorijskoj razini jest aktualizacija izdvajanja parcijalnih turističkih otisaka, a na aplikativnoj razini izračun otisaka kao podloge za razvoj strategija i planova za održivi razvoj otočnih i ostalih prostora. U konačnici ukupan cilj rada jest doprinos revitalizaciji i održivom razvoju otoka kao visokovrijednih prostora.

\section{Izvori i metode}

Istraživanje se oslanja na radove koji se bave utjecajem turizma na opterećenje okoliša izračunom ekološkog otiska (Hunter, 2002; Hunter i Shaw, 2007) te specifično određivanjem utjecaja turizma na atmosfersku emisiju $\mathrm{CO}_{2}$, odnosno određivanjem ugljikova otiska turizma (Gössling, 2011; Grofelnik, 2010, 2012).

Za izračun ekološkog otiska, odnosno parcijalnog ugljikova otiska pomorskog prometa, poslužili smo se podacima tvrtke Jadrolinija, koja je jedini cjelogodišnji linijski pomorski prijevoznik na otocima Cresu i Lošinju. Uz dobivene statističke podatke za izračun ugljikova otiska pomorskog prometa primijenjeni su standardni postupci u metodi izračuna ugljikova otiska (Ewing i dr., 2008). Na primjeru studije slučaja ugljikova otiska cjelogodišnjega linijskog pomorskog prometa izračunat je njegov ukupni utjecaj na okoliš te je specifično izdvojen udio turizma u tom otisku.

S obzirom na medij odvijanja pomorskog prometa izračunate vrijednosti emisije $\mathrm{CO}_{2}$ stavljene su u omjer s lokalnom sposobnošću apsorpcije $\mathrm{CO}_{2}$ Sjevernog Jadrana, odnosno morske površine koja pripada otocima Cresu i Lošinju (Laruelle i dr., 2010; Turk i dr., 2010). Za površinu mora koja pripada otocima Cresu i Lošinju, odnosno cresko-lošinjskom arhipelagu, uzeta je morska površina teritorijalnih jedinica lokalne samouprave Grad Cres i Grad Mali Lošinj, koja iznosi 3064 km².
A regular annual sea transport carbon footprint for the islands of Cres and Lošinj

Ugljikov otisak cjelogodišnjega linijskog pomorskog prometa na otocima

Cresu i Lošinju 
GEOGRAFSKI

GLASNIK

77/2, 73-83 (2015.)

\section{Results and discussion}

\section{Carbon footprint calculations}

By isolating the sea transport's partial ecological (carbon) footprint for the islands of Cres and Lošinj, a significant amount of the $\mathrm{CO}_{2}$ atmospheric emissions of the observed area was covered (Grofelnik, 2011). The sea transport in this carbon footprint research implies organized annual sea transport ${ }^{1}$,which includes the major part of the islands' sea transport ${ }^{2}$. Due to strong tourism activity, the main characteristic of the annual sea transport's trend is its pronounced seasonality.

\section{Rezultati i rasprava}

\section{Izračun ugljikova otiska}

Izdvajanjem parcijalnoga ekološkog (ugljikova) otiska pomorskog prometa na otocima Cresu i Lošinju obuhvaćena je značajna količina emisije $\mathrm{CO}_{2} \mathrm{u}$ atmosferu promatranog prostora (Grofelnik, 2011). Pod pomorskim prometom u ovom istraživanju ugljikova otiska podrazumijeva se organizirani cjelogodišnji linijski pomorski promet ${ }^{1}$, koji čini najveći dio pomorskog prometa ${ }^{2}$ na otocima. Zbog naglašenih turističkih kretanja osnovno obilježje godišnjega kretanja pomorskog prometa njegova je izrazita sezonalnost.

Tab. 1 Fuel consumption on regular annual ferry routes for the islands of Cres and Lošinj in 2008. (liters of diesel fuell.

Tab. 1. Potrošnja goriva po cjelogodišnjim trajektnim linijama na otocima Cresu i Lošinju tijekom 2008. godine (litre dizel goriva)

\begin{tabular}{|c|c|c|c|c|c|c|c|c|c|c|c|c|}
\hline 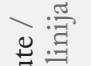 & \multicolumn{12}{|c|}{ Months / Mjeseci } \\
\hline 式造 & I. & II. & III. & IV. & V. & VI. & VII. & VIII. & IX. & $\mathrm{X}$. & XI. & XII. \\
\hline 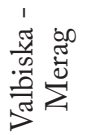 & 68415 & 65768 & 73777 & 75903 & 98234 & 107636 & 121946 & 121947 & 98094 & 72862 & 61630 & 66720 \\
\hline 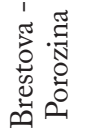 & 58408 & 60511 & 64721 & 77870 & 107802 & 118169 & 117430 & 126588 & 94480 & 51432 & 37710 & 60151 \\
\hline 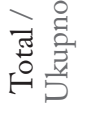 & 126823 & 126279 & 138498 & 153773 & 206036 & 225805 & 239376 & 248535 & 192574 & 124294 & 99340 & 126871 \\
\hline
\end{tabular}

Source: Jadrolinija, 2009.

Izvor: Jadrolinija, 2009.

\footnotetext{
1 The regular annual sea transport in the archipelago of Cres and Lošinj is carried out by the Jadrolinija Company, and it covers the ferry routes Valbiska - Merag and Brestova - Porozina, the high speed catamaran route Rijeka - Cres - Martinišćica - Unije - Mali Lošinj, and the ship route Unije - Ilovik - Susak - Srakane - Mali Lošinj.

1 Cjelogodišnji linijski pomorski promet u akvatoriju otoka Cresa i Lošinja obavlja tvrtka Jadrolinija, a obuhvaća trajektne linije Valbiska - Merag i Brestova - Porozina, brzobrodsku (katamaransku) liniju Rijeka - Cres - Martinšćica - Unije - Mali Lošinj te brodsku liniju Unije - Ilovik - Susak Srakane - Mali Lošinj.

2 Sea transport that is not annual includes extraordinary routes of private shipping companies and smaller private vessels, while there is also irregular sea transport, as well as many other forms of sea transport throughout the year. The foregoing types of sea transport were not included in this research due to inability to track statistical indexes of transport and fuel consumption.

2 Pomorski promet koji nije cjelogodišnjeg tipa obuhvaća neredovite linije privatnih brodara, manja osobna plovila, a tijekom godine pojavljuje se i izvanredni pomorski prijevoz, kao i ostali oblici pomorskog prometa. Navedeni oblici pomorskog prometa nisu obuhvaćeni istraživanjem zbog nemogućnosti praćenja statističkih pokazatelja prometa i potrošnje pogonskoga goriva.
} 
Tab. 2 Fuel consumption on regular annual speedboat and ship routes for the islands of Cres and Lošinj in 2008. (liters of diesel fuell. Tab. 2. Potrošnja goriva na cjelogodišnjim brzobrodskim i brodskim linijama na otocima Cresu i Lošinju tijekom 2008. godine (litre dizel goriva)

\begin{tabular}{|c|c|c|c|c|c|c|c|c|c|c|c|c|}
\hline \multirow{2}{*}{ 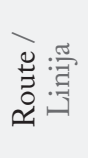 } & \multicolumn{12}{|c|}{ Months / Mjeseci } \\
\hline & I. & II. & III. & IV. & V. & VI. & VII. & VIII. & IX. & $X$. & XI. & XII. \\
\hline 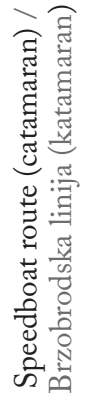 & 101231 & 105086 & 111187 & 106159 & 123346 & 124609 & 128874 & 131175 & 117363 & 113717 & 100196 & 86246 \\
\hline 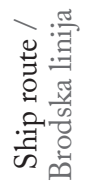 & 15650 & 16886 & 17827 & 16930 & 20194 & 23118 & 24035 & 23845 & 23102 & 23878 & 20817 & 17885 \\
\hline
\end{tabular}

Source: Jadrolinija, 2009.

Izvor: Jadrolinija, 2009.

Local footprint calculations have been made dividing fuel consumption of ferries and catamarans (theirs carbon emissions) with the sea area (its carbon absorption), which covers part of local territorial units. Since the significant parts of sea routes of ferries and catamarans are outside of the local territorial units of the Cities of Cres and Mali Lošinj, a correction of the total fuel consumption was carried out (Tab. 3). Fuel consumption of both ferry routes was decreased by $50 \%$ because half of the route lines belong to the neighbouring territorial units (the City of Krk for the Valbiska - Merag line, and the $\mathrm{Mu}^{-}$ nicipality of Kršan for the Brestova - Porozina line), while the fuel consumption of the catamaran route was decreased by $10 \%$ because one tenth of the route line is outside of the islands' territorial units and belongs to the local carbon footprint of the City of Rijeka territorial unit. No correction is needed for ship fuel consumption since the entire route lies within the observed local territorial unit area and makes up in its entirety the local carbon footprint of the Cities of Cres and Mali Lošinj. The corrections of fuel consumption do not affect the aspect of the annual vari-
Izračuni lokalnog otiska izrađeni su dijeljenjem potrošnje goriva trajekata i katamarana (njihovih ugljikovih emisija) s površinom mora (njegovim apsorpcijskim kapacitetom) koja pripada jedinicama lokalne samouprave. Budući da značajni dijelovi pomorskog puta trajekata i katamarana izlaze iz područja teritorijalnih jedinica Grada Cresa i Grada Malog Lošinja, napravljena je korekcija potrošnje goriva koja se odnosi na lokalni otisak (tab. 3). Potrošnja goriva za obje trajektne linije smanjena je u izračunu otiska za $50 \%$ jer polovina pomorskog puta trajekata pripada susjednim teritorijalnim jedinicama (Grad Krk za liniju Valbiska - Merag, Općina Kršan za liniju Brestova - Porozina), dok je potrošnja goriva za pomorski put katamarana smanjena za $10 \%$ jer se desetina duljine linije nalazi izvan područja otočnih teritorijalnih jedinica i pripada lokalnom ugljikovu otisku teritorijalne jedinice Grad Rijeka. Za potrošnju goriva brodskog prometa korekcija nije bila potrebna jer se cjelokupni pomorski put brodske linije nalazi unutar otočnih teritorijalnih jedinica Grada Cresa i Grada Malog Lošinja. Korekcije potrošnje goriva ne utječu na godišnje oscilacije potrošnje, vidljive usporedbom
A regular annual sea transport carbon footprint for the islands of Cres and

Lošinj

Ugljikov otisak cjelogodišnjega linijskog pomorskog prometa na otocima

Cresu i Lošinju 
HRVATSKI

GEOGRAFSKI

GLASNIK

77/2, 73-83 (2015.)

ation of consumption, which can be seen comparing the related diagrams (Fig. 2, Fig. 3).

Tab 3. Corrected total fuel consumption of the regular annual sea transport for the islands of Cres and Lošinj in 2008. (liters of diesel fuel).

Tab. 3. Korigirana ukupna potrošnja goriva cjelogodišnjeg linijskog pomorskog prometa na otocima Cresu i Lošinju tijekom 2008. godine (litre dizel goriva

\begin{tabular}{|c|c|c|c|c|c|c|c|c|c|c|c|c|}
\hline \multirow{2}{*}{ 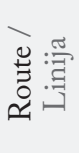 } & \multicolumn{12}{|c|}{ Months / Mjeseci } \\
\hline & I. & II. & III. & IV. & V. & VI. & VII. & VIII. & IX. & $\mathrm{X}$. & XI. & XII. \\
\hline 爮 & 63412 & 63140 & 69249 & 76887 & 103018 & 112903 & 119688 & 124268 & 96287 & 62147 & 49670 & 63435 \\
\hline 啫 & 15650 & 16886 & 17827 & 16930 & 20194 & 23118 & 24035 & 23845 & 23102 & 23878 & 20817 & 17885 \\
\hline 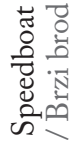 & 91108 & 94577 & 100068 & 95543 & 111011 & 112148 & 115987 & 118058 & 105627 & 102345 & 90176 & 77621 \\
\hline 䒿䓂 & 170170 & 174603 & 187144 & 189360 & 234223 & 248169 & 259710 & 266171 & 225016 & 188370 & 160663 & 158941 \\
\hline
\end{tabular}

Source: Jadrolinija, 2009.

Izvor: Jadrolinija, 2009.

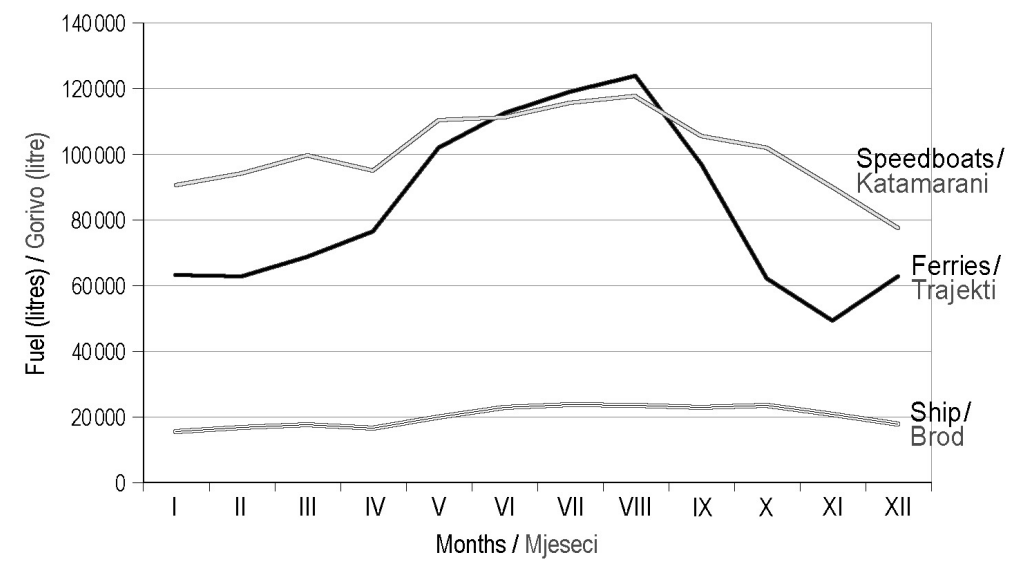

Fig. 2. Annual variation of corrected total fuel consumption of regular annual sea transport for the islands of Cres and Lošinj in 2008. (liters of diesel fuel)

SI. 2. Godišnji hod korigirane ukupne potrošnje goriva cjelogodišnjega linijskog pomorskog prometa na otocima Cresu i Lošinju tijekom 2008. (litre dizelskoga goriva)

Source: Jadrolinija, 2009.

Izvor: Jadrolinija, 2009.

\section{8}


The total corrected fuel quantity consumed by the annual sea transport within the Cres - Lošinj archipelago is 2462540 litres of diesel fuel or 2191 $661 \mathrm{~kg}$ of diesel fuel ${ }^{3}$. If one takes into account that the efficiency by the kilogram of fuel for the ships involved was at the global average level ${ }^{4}$, that results in atmospheric emission of $6947565 \mathrm{~kg} \mathrm{CO}$ in 2008. The absorption capacity of atmospheric $\mathrm{CO}_{2}$ of the Northern Adriatic Shelf, i.e. a carbon sink, used for calculating ecological (carbon) footprint, is $-2.2 \mathrm{C} \mathrm{mol} / \mathrm{m}^{2}$ annually, or around $968 \mathrm{~kg} \mathrm{CO} /$ ha annually (Laruelle et al., 2010; Turk et al., 2010).

The absorption capacity of sea areas in the Cres Lošinj archipelago of $296595200 \mathrm{~kg} \mathrm{CO}$ per year was calculated using the above data. By putting annual sea transport's $\mathrm{CO}_{2}$ emission in relation with absorption values of the Cres - Lošinj sea, we arrive at $7177 \mathrm{lha}^{5}$ or around $2.3 \%$ of the sea absorption capacity occupied.

\section{The share of non-residents in the carbon footprint}

Through the analysis of annual trends in the fuel consumption and the numbers of tourist arrivals on Cres and Lošinj, it is evident that there is a significant match of values that is dominantly the result of tourism activity and trends (Fig. 3).

The tourists' ecological footprint in the entire regular annual sea transport (tourist footprint), since almost all tourists arrive by sea, is around $36.5 \%$ of the total footprint. This value was calculated by taking November as the base month, because it recorded the lowest intensity of tourism activity on the islands (TB-CC 2009; TB-CML 2009). This basis was taken further as the value that covers transportation needs of the island communities. Values for all the other months that show higher
Ukupna korigirana količina goriva utrošena za cjelogodišnji linijski pomorski prijevoz za potrebe cresko-lošinjskog arhipelaga iznosi 2.462.540 litara dizelskoga goriva ili $2.191 .661 \mathrm{~kg}$ dizelskoga goriva ${ }^{3}$. Ako se pretpostavi da je iskoristivost po kilogramu pogonskoga goriva brodova koji su sudjelovali u prijevozu bila na razini svjetskog prosjeka ${ }^{4}$, dobiva se atmosferska emisija tijekom 2008. godine od $6.947 .565 \mathrm{~kg} \mathrm{CO}$. Sposobnost apsorpcije atmosferskog $\mathrm{CO}_{2}$ sjevernojadranskog šelfa, odnosno carbon sink upotrijebljen za izračun ekološkog (ugljikova) otiska, iznosi godišnje $-2,2 \mathrm{CO}_{2} \mathrm{~mol} / \mathrm{m}^{2}$ ili oko 968 $\mathrm{kg} \mathrm{CO}_{2}$ /ha godišnje (Laruelle i dr., 2010; Turk i dr., 2010).

Iz navedenih podataka dobivena je sposobnost apsorpcije morskih površina cresko-lošinjskog arhipelaga od 296.595.200 $\mathrm{kg} \mathrm{CO}$ godišnje. Stavljanjem u omjer emisije $\mathrm{CO}_{2}$ linijskoga pomorskog cjelogodišnjeg prijevoza i vrijednosti apsorpcije cresko-lošinjskog akvatorija dobiva se zauzetost kapaciteta apsorpcije mora od $7177 \mathrm{lha}^{5}$ ili oko 2,3\%.

\section{Udio nerezidenała u ugljikovu otisku}

Analizom godišnjega hoda vrijednosti i trendova u potrošnji pogonskoga goriva te kretanja broja turističkih dolazaka na Cres i Lošinj može se uočiti značajna podudarnost, koja je dominantno rezultat turističkih kretanja (sl.3).

Ekološki otisak cjelogodišnjega linijskog pomorskog prijevoza od turista (turistički otisak), koji gotovo svi dolaze pomorskim prijevozom, iznosi oko 36,5 \% ukupnog otiska. Taj udio dobiven je tako da je za bazni mjesec uzet studeni, u kojem je zabilježen najmanji intenzitet turističke aktivnosti na otocima (TZ-GC, 2009; TZ-GML, 2009). Ta je baza uzeta kao vrijednost koja zadovoljava prometne potrebe otočne zajednice. Vrijednosti ostalih mjeseci,

\footnotetext{
3 Litres of diesel fuel have been converted into $\mathrm{kg}$ to calculate the emission of $\mathrm{CO}_{2}$ gas. The density of marine diesel fuel (produced by INA d.d.) in Croatia is $0.89 \mathrm{~kg} / 1$ (INA, 2011).

3 Litre dizelskoga goriva pretvorene su u kilograme kako bi se izračunala emisija $\mathrm{CO}_{2}$. Gustoća brodskoga dizelskoga goriva (koji je proizvela INA d.d.) u Hrvatskoj iznosi 0,89 kg/1 (INA, 2011).

4 The average sea transport's CO2 emission by $1 \mathrm{~kg}$ of diesel fuel is $3.17 \mathrm{~kg} \mathrm{CO} 2$ (IMO, 2000).

4 Prosječna emisija CO2 brodskog prijevoza po litri pogonskoga dizelskoga goriva iznosi 3,17 kg CO2 (IMO, 2000).

$5 \mathrm{lha}$ (local hectare) is a unit used in the ecological footprint method for the carbon (ecological) footprint (Ewing et al., 2008). Local hectare shows the capacity of local and real surface, respectively, which has its own specific atmospheric $\mathrm{CO}_{2}$ absorption capacity.

5 Lokalni hektar, lha, jest mjerna jedinica za ugljikov (ekološki) otisak koja se upotrebljava u metodi ekološkog otiska (Ewing i dr., 2008). Lokalni hektar prikazuje sposobnost lokalne odnosno realne površine u prostoru koja ima svoju specifičnu sposobnost apsorpcije atmosferskog CO2..
}

A regular annual sea transport carbon footprint for the islands of Cres and Lošinj

Ugljikov otisak cjelogodišnjega linijskog pomorskog prometa na otocima Cresu i Lošinju 
HRVATSKI

GEOGRAFSKI

GLASNIK

77/2, 73-83 (2015.)
Tab. 4 Oscillations in the sea transport's fuel consumption for the islands of Cres and Lošinj above the base month in 2008.

Tab. 4. Oscilacije potrošnje goriva pomorskog prometa na otocima Cresu i Lošinju iznad baznog mjeseca tijekom 2008. godine

\begin{tabular}{|c|c|c|c|c|c|c|c|c|c|c|c|c|}
\hline . & & & & & & Months & / Mjeseci & & & & & \\
\hline $\begin{array}{ll} & 0 \\
0 & 0 \\
0 & 0 \\
0\end{array}$ & I. & II. & III. & IV. & V. & VI. & VII. & VIII. & IX. & X. & XI. & XII. \\
\hline 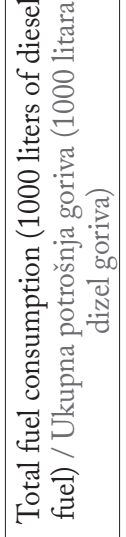 & 68415 & 65768 & 73777 & 75903 & 98234 & 107636 & 121946 & 121947 & 98094 & 72862 & 61630 & 66720 \\
\hline 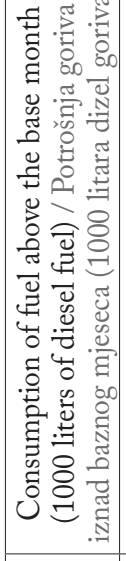 & 58408 & 60511 & 64721 & 77870 & 107802 & 118169 & 117430 & 126588 & 94480 & 51432 & 37710 & 60151 \\
\hline 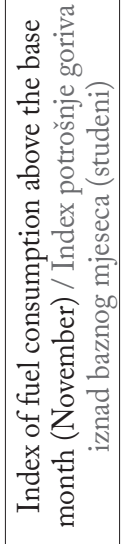 & . & 126279 & 138498 & 153773 & 206036 & 225805 & 239376 & 248535 & 192574 & 124294 & 99340 & 126871 \\
\hline
\end{tabular}

Source: Jadrolinija, 2009.

Izvor: Jadrolinija, 2009.

80 
frequencies were taken as the result of non-resident, mostly tourist, activities in the area (Tab. 4; Fig. 3).

The ratio in vessel utilization, as per the number of vehicles on the ferries during the winter months and during the summer tourist season, shows a koji imaju veće frekvencije, uzete su kao posljedica nerezidentnih, a prije svega turističkih, kretanja u prostoru (tab. 4, sl. 3).

Odnos iskorištenosti plovila, prema broju vozila na trajektima, tijekom zimskih mjeseci i tijekom

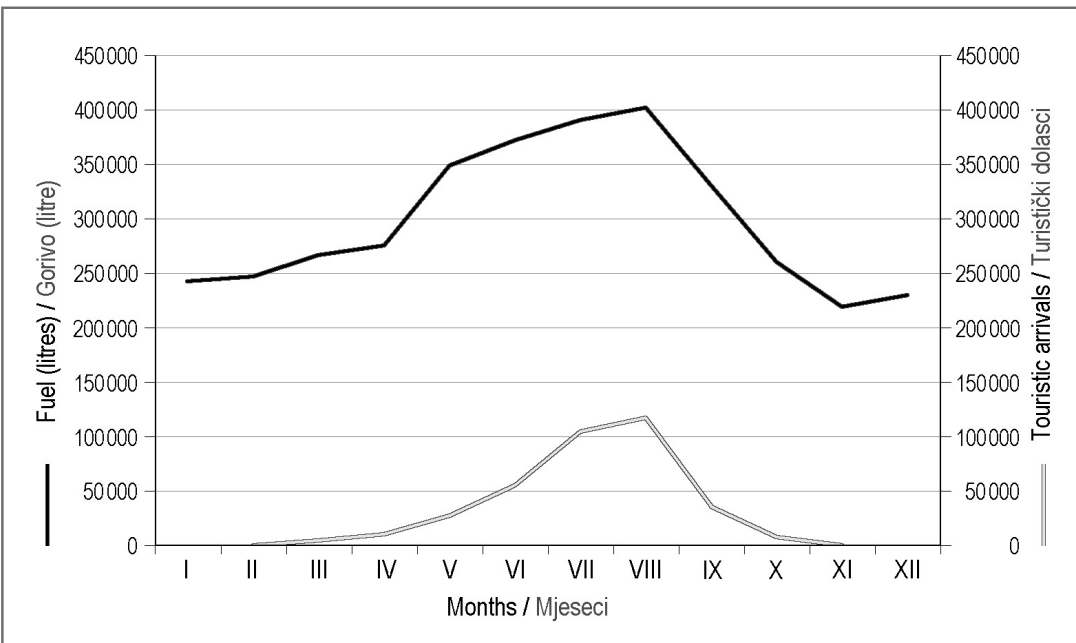

A regular annual sea transport carbon footprint for the islands of Cres and Lošinj

Ugljikov otisak cjelogodišnjega linijskog pomorskog prometa na otocima Cresu i Lošinju

Fig. 3 The ratio of fuel consumption in regular annual sea transport and the trends of tourist arrivals for the islands of Cres and Lošinj in 2008.

SI. 3. Odnos hoda potrošnje goriva cjelogodišnjega linijskog pomorskog prijevoza i hoda turističkih dolazaka na otocima Cresu i Lošinju tijekom 2008.

Source: Jadrolinija, 2009.; TB-CC, 2009.; TB-CML, 2009.

Izvor: Izvor: Jadrolinija, 2009.; TZ-GC, 2009.; TZ-GML, 2009.

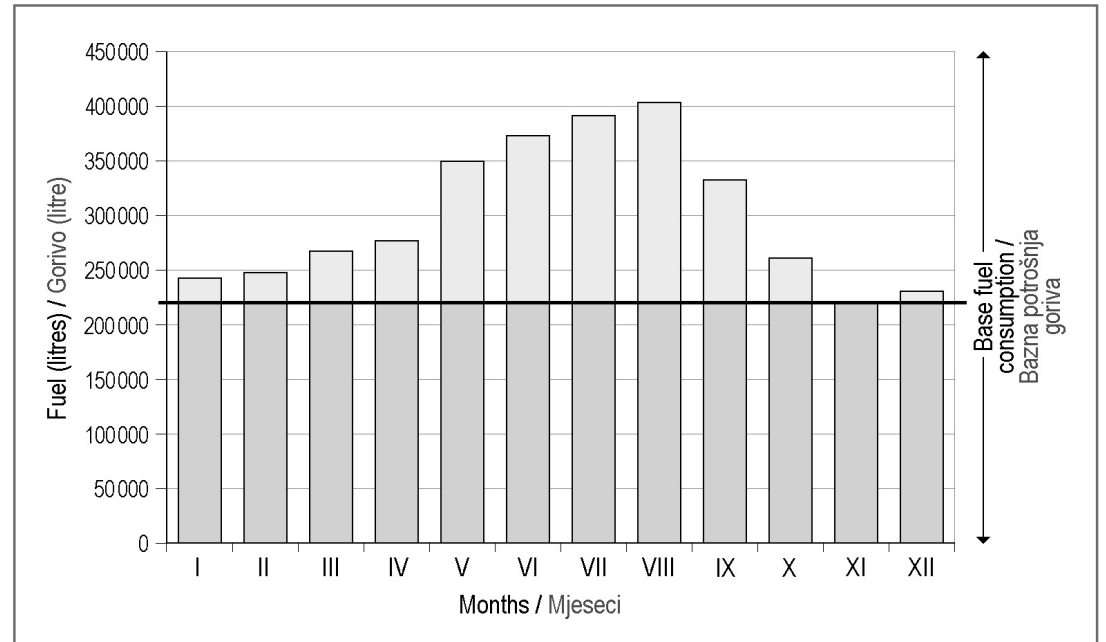

Fig. 4. The base and fuel consumption trends in the regular annual sea transport for the islands of Cres and Lošinj in 2008.

SI. 4. Kretanje baze i potrošnje goriva u cjelogodišnjemu linijskom pomorskom prijevozu na otocima Cresu i Lošinju tijekom 2008.

Source: Jadrolinija, 2009.

Izvor: Jadrolinija, 2009. 
GEOGRAFSKI

GLASNIK

77/2, 73-83 (2015.) visible increase in energy efficiency during summer months. The utilization of the vessels' full capacity during summer months decreases expenses and allows for the decrease of the total footprint, as well as the lower contribution of the tourist footprint in the footprint generated by non-residents outside of the tourist season (Fig. 4).

\section{Conclusion}

The ecological footprint of the regular annual sea transport for the islands of Cres and Lošinj in relation to the absorption capacity of the archipelago in question was around $2.3 \%$ in 2008, which is a relatively low value, making possible and justifying the further development of this type of transport. The regular annual sea transport share in the $\mathrm{CO}_{2}$ emission in 2008, which was generated for the needs of non-residents on the island (tourist footprint), was around 36.5\%, meaning that the largest influence on the environment by the regular annual sea transport relates directly to the needs of the resident population. This is due to the fact that vessels' capacities do not change significantly over the year while, during winter, ferries and other vessels usually have very low capacity utilization. Therefore, it is clear that the starting hypothesis, which is the basis for this research, is partially correct. The part of the hypothesis that says that the sea transport's total carbon footprint is dominantly under the influence of tourism turned out to be incorrect, while the part of the hypothesis that says that annual oscillations in the footprint are closely related to the tourism activity on the islands is correct. The results show the need for further detailed research (case studies) of environmental impacts of non-regular and seasonal sea transport. Still, the results obtained even at this level may be taken into consideration when developing future strategies and plans for the sustainable development of the islands of Cres and Lošinj. ljetne turističke sezone upućuje na uočljivo povećanje energetske efikasnosti u ljetnim mjesecima. Iskorištavanje punoga kapaciteta plovila u ljetnim mjesecima smanjuje troškove i pogoduje smanjenju ukupnog otiska, odnosno ukupno manjem sudjelovanju turističkog otiska prema otisku koji generira rezidentno stanovništvo izvan turističke sezone (sl. 4).

\section{Zaključak}

Ekološki otisak cjelogodišnjega linijskog pomorskog prijevoza na otocima Cresu i Lošinju u odnosu na kapacitet apsorpcije njihova pripadajućeg arhipelaga iznosio je za 2008. godinu oko 2,3 $\%$, što je relativno malo te omogućuje i opravdava daljnji razvoj tog oblika prometnog povezivanja otoka. Udio cjelogodišnjega linijskog pomorskog prometa u emisiji $\mathrm{CO}_{2}$ tijekom 2008. godine, generiran za potrebe nerezidenata na otoku (turistički otisak), iznosio je oko $36,5 \%$, odnosno najveći udio utjecaja na okoliš cjelogodišnjega linijskog pomorskog prijevoza odnosi se na potrebe rezidentnog stanovništva. To je posljedica kapaciteta plovila koji se značajnije ne mijenja tijekom godine te se često dogodi da trajekti i ostala plovila u zimskom razdoblju imaju vrlo malu iskorištenost kapaciteta, iz čega je vidljivo da je početna hipoteza na kojoj se zasniva rad djelomično točna. Dio hipoteze koji tvrdi da je ukupni ugljikov otisak pomorskog prometa dominantno pod utjecajem turizma pokazao se netočnim, dok se točnim pokazao dio hipoteze da su godišnje oscilacije otiska usko vezane uz aktivnost turizma na otocima. Rezultati rada upućuju na potrebu detaljnijih istraživanja (studija slučaja) utjecaja na okoliš neredovitih i sezonskih pomorskih linija. Ipak, već na ovoj razini dobivene je rezultate moguće uzeti u obzir pri izradi budućih strategija i planova održivoga razvoja otoka Cresa i Lošinja. 
A regular annual sea transport carbon footprint for the islands of Cres and Lošinj

Ewing, B., Reed, A., Rizk, S. M., Galli, A., Wackernagel, M., Kitzes J., 2008: Calculation methodology for the national footprint accounts, Edition, Oakland: Global Footprint Network.

Gössling, S., 2011: Carbon management in tourism: mitigating the impacts on climate change, Routledge, New York.

Grofelnik,H., 2010: Ecological footprint of road traffic on Cres-Lošinj Archipelago, Geoadria 15 (2), 269-286.

Grofelnik, H., 2011: Ecological aspect of sustainable development of tourism on the islands of Cres and Losinj, doctoral dissertation, Department of Geography, Faculty of Science, University of Zagreb.
Grofelnik, H., 2012: The Local ElectroEnergetic Carbon Footprint Generated by Tourism on the Islands of Cres and Lošinj, Geoadria 17 (2), 235-244.

Hunter, C., 2002: Sustainable tourism and the touristic ecological footprint, Environment, Development and Sustainability 4, 7-20.

Hunter, C., Shaw, J., 2007: The ecological footprint as a key indicator of sustainable tourism, Tourism Management 28, 46-57.

Laruelle, G. G., Dürr, H. H., Slomp, C. P., Borges, A. V., 2010: Evaluation of inks and sources of $\mathrm{CO}_{2}$ in the global coastal ocean using a spatially explicit typology of estuaries and continental shelves,
Geophysical Research Letters 37, L15607, doi:10.1029/2010GL04369, 1-20.

Lukić, A., 2012: Mosaic Outside of City typology of rural and urbanized settlements in Croatia, Meridijani, Samobor.

Piecyk, M. I., McKinnon, A. C., 2009: Environmental Impact of Road Freight Transport in 2020, Heriot-Watt University, Edinburgh.

Turk, D., Malačić, V., DeGrandpre, M. D., McGillis, W. R., 2010: Carbon dioxide variability and air-sea fluxes in the northern Adriatic Sea, Journal of Geophysical Research 115, C10043, doi:10.1029/2009JC006034, 1-12.

IMO - International Maritime Organization, 2000: Study of greenhouse gas emissions from ships, No. 2, 1-169

INA - Oil company: Catalogue of fuel 2011

INA - Industrija nafte d.d. Katalog goriva 2011

Jadrolinija, 2009: Data provided by Jadrolinija - sea shipping company

Jadrolinija, 2009: podaci dobiveni od Jadrolinije

TB-CC, 2010: Data provided by City of Cres Tourist Bord

TB-CC, 2010: podaci dobiveni od Turističke zajednice Grada Cresa

TB-CML, 2010: Data provided by City of Mali Lošinj Tourist Board

TB-CML, 2010: podaci dobiveni od Turističke zajednice Grada Malog Lošinja 